\title{
Se há transgressão no teatro paulistano contemporâneo: gestos e imagens
}

Whether there is transgression in contemporary theatre in São Paulo: gestures and images

Artur Sartori Kon ${ }^{1}$ 


\section{Resumo}

A partir de cenas e imagens de algumas obras teatrais produzidas recentemente em São Paulo, Brasil, procuramos investigar a possibilidade e o sentido de se falar em alguma transgressão nesse teatro, opondo à ideia de um teatro "performativo" (baseado no gesto que visa a uma passagem do campo do estético para o da práxis) uma visão que pretendemos mais complexa: a de uma potência transgressora das imagens mesmas e do próprio estético.

Palavras-chave: Teatro paulistano; Teatro contemporâneo; estética e política; política das imagens; transgressão nas artes

\section{Abstract}

Starting from scenes and images from theatrical works recently produced in Sao Paulo, Brazil, we have tried to investigate the possibility and meaning of speaking of some transgression in this theatre, opposing to the idea of a "performative" theatre (founded on the gesture intending to pass from the field of aesthetics to that of praxis) a vision we believe more complex: that of a transgressive power of images themselves and of aesthetics in itself.

Keywords: Theatre in São Paulo; Contemporary theatre; aesthetics and politics; politics of images; transgression in art

ISSN: 1414.5731

E-ISSN: 2358.6958

${ }^{1}$ Doutorando pelo Departamento de Filosofia da FFLCH-USP, na área de Estética e Filosofia da Arte. Ator da Cia de Teatro Acidental. arturskon@gmail.com 
Ao apressar-se em amaldiçoar a ideia de espetáculo, reduzindo-a à de ineficiência, cai-se no engodo semelhante ao de opor os verdadeiros atos às vãs palavras: o mesmo que esquecer os poderes da linguagem. [...] o desprezo dos outros que se manifesta no blefe de alguns atos não justifica que seja censurada a capacidade que tem a conduta de formar imagem.

Jean Galard (2008, p. 70)

Em julho de 2010, pudemos assistir (durante o 23을 Festival Internacional de Teatro Universitário de Blumenau) ao espetáculo de intervenção urbana A cena é pública, do coletivo carioca Teatro de Operações, grupo empenhado na "pesquisa de formas de conjugar arte e ativismo político, através da criação de operações para teatro de rua" - sendo "operação artística [...] o termo usado pelo grupo em oposição à ideia de obra de arte" (Teatro de Operações, 2013a). O trabalho se constituía por quadros independentes, ações disruptivas do cotidiano urbano em que se inseriam: desde o aparecimento dos performers em lugares inusitados e supostamente proibidos, como lajes de prédios em redor da praça onde a apresentação tinha lugar, até a destruição de uma pilha de aparelhos de televisão por um dos artistas, armado de uma marreta, passando por uma lavagem de diversas bandeiras nacionais na fonte da praça e ainda pela formação de uma arena de combate onde se enfrentavam atores portando máscaras que figuravam os três principais candidatos às eleições presidenciais daquele ano. Em todos os casos, as atividades pareciam aspirar a certa radicalidade, ou seja, a uma potência de interrupção dos modos habituais de experiência de seus espectadores ${ }^{2}$, instaurando-se como força alternativa, algo que poderíamos ver como uma forma de transgressão.

De algum modo, parece que essa maneira de conceber o trabalho teatral proliferou recentemente, sendo a intervenção urbana uma das formas de criação mais exploradas por artistas interessados em romper os limites do fenômeno cênico tradicionalmente compreendido. Corresponde a proposições teóricas como as de Josette Féral (2008) e Erika Fischer-Lichte (2008), que descrevem o teatro contemporâneo como fundamentalmente "performativo", ou diversas teorias do "teatro do real" (ver Saison, 1998, Sánchez, 2007 e Fernandes, 2013) que busca superar o campo da mimese e da ficção em direção à realidade nua, seja ela autobiográfica, documental, corporal ou contextual ${ }^{3}$. Não obstante diferenças pontuais entre essas diferentes formulações, parece haver tanto na produção cênica contemporânea quanto em sua teorização uma renovada busca de desobedecer ou mesmo violar agressivamente as fronteiras impostas às obras e práticas pela sua crescente institucionalização e aceitação geral, como se fosse possivel recuperar algo do que as vanguardas históricas outrora almejaram, isso é: uma passagem do campo isolado do estético para o do mundo da vida, da práxis social efetiva. Os alvos principais desse tipo de postura combativa são as já muito atacadas representação, compreendida como déficit de presença ou excesso de mediação, e imagem, vista como cúmplice de uma generalização do estético midiático na chamada sociedade do espetáculo.

\footnotetext{
${ }^{2}$ Como falava para os próprios artistas a pesquisadora e professora da UFMG Bya Braga, "o que está posto nesta cena de vocês, para nós, é uma invasão, antes mesmo do espaço, de nossas percepções. O público se sente invadido na sua expectativa de obra de arte, do teatro" (apud Teatro de Operações, 2013b). Já a pesquisadora Jussara Trindade (apud ibid.) destacava a "proposta de ruptura dos condicionamentos cotidianos daquele ambiente urbano e social". 0 próprio coletivo enfatizava na peça o "gesto em direção às micro potências desviantes", e comemorava o comentário feito por um "policial militar em serviço ao se deparar com uma operação": "É protesto, teatro ou ato público?" (ibid.).
} 
De fato, é notável como certa produção teatral do século XXI abandona tropos pós-modernos da distância e do pastiche em prol do engajamento franco com o campo da política e do social, pensando contudo esse compromisso não mais de modo apenas racional e iluminista, como supostamente teria sido o teatro político do século XX (representado sobretudo por Bertolt Brecht, modelo maior do teatro paulistano dos anos 90), mas implicando profundamente corpos e subjetividades dos envolvidos, gerando uma experiência marcadamente pessoal (é o que propõe Lavander, 2015). Mas caberá mesmo abordar tal produção como uma nova vanguarda capaz de completar o embaralhamento de arte e vida em que seus precursores fracassaram? Cenas como as propostas pelo Teatro de Operações (e mesmo o conceito que dá nome ao grupo, como definido acima) não recairão necessariamente num certo clichê das ações revolucionárias, ou mesmo num fetiche do que seria uma arte transgressora? Não estaria em curso, muito mais do que uma nova onda de inovação e transgressão capaz de apontar um novo rumo político para o teatro e para as artes em geral, e apesar das melhores intenções dos artistas que encabeçam essa produção, na verdade uma mercantilização da atitude de revolta, algum tipo de dessublimação repressiva (ver Marcuse, 2002)? Ou seja, poder-se-ia dizer a respeito dessas proposições cênicas que "o fato de que elas contradizem a sociedade que as vende não conta" à medida que são reinseridas e reduzidas ao denominador comum de todas as áreas da cultura na sociedade capitalista contemporânea, qual seja, a forma mercadoria (Marcuse, 2002, p. 60-61): a ação que pretende romper radicalmente com a imagem mediada recai no espetáculo.

Estaria, pois, o teatro contemporâneo fadado ao fracasso e ao conformismo? Para evitar a resposta afirmativa a essa perigosa e urgente questão, é preciso repensar o lugar de um dissenso possível nas práticas artísticas atuais, descobrir certa performatividade da cena que não é a de uma cena performativa, aprender a diferenciar a imagem-fetiche de transgressão da verdadeira força transgressora da imagem. Nas páginas que seguem, buscaremos localizar essa potência em alguns dos mais interessantes projetos e grupos do teatro paulistano contemporâneo, de modo a - quem sabe - redescobrir alguma confiança no sentido político do fenômeno teatral.

\section{Pulsão de morte, pulsão de imagem}

Quase um ano após nossa experiência com $A$ cena é pública, estreava em São Paulo a peça (ver[ ]ter), da Cia Les Commediens Tropicales ${ }^{4}$. Estruturalmente, parece seguir um caminho bastante parecido ao do grupo carioca: a "criação cênica de caráter intervencionista" (Les Commediens Tropicales, 2012) é constituída por quadros independentes entre si, desenvolvidos normalmente em pontos diferentes de deter-

\footnotetext{
${ }^{3}$ As teorias dos "teatros do real" buscam descrever uma produção que partiria da "premissa de que há no teatro e performance contemporâneos uma tendência em qualificar como melhor [...] o que é ao vivo e imediato", como avalia Luiz Fernando Ramos (2011, p. 63); para Silvia Fernandes, as mais relevantes obras teatrais recentes seriam "sintomas da necessidade de encontrar experiências 'verdadeiras', 'reais', colhidas em práticas extra-cênicas e vivenciadas na exposição imediata do performer diante do espectador" (2013, p. 6), "em oposição à relação mimética, abstrata, da representação com aquilo que representa [...] [e] em proveito da presentação única, singular" como "reivindicação de acesso imediato ao real" (ibid., p. 4). De modo semelhante, o performativo, em oposição ao caráter ficcional tradicionalmente atribuído ao teatro, buscaria se estabelecer no campo do acontecimento e da presença como ruptura da representação: "o teatro aspira a produzir evento, acontecimento, reencontrando o presente", defende Féral (2011, p. 209); já Ramos (2015, p. 96) nota que "há certa confusão na compreensão" do conceito do performativo, "a partir da mescla de aspectos adjetivos, ou seja, de se pensar o performativo como meramente afeito à performance, com seu caráter substantivo, o de ser alguma coisa que perfaz uma ação concreta".
} 
minada área urbana, e concebida a partir do encontro de "diversas manifestações artísticas, como o grafite, a vídeo art, a performance art, o teatro, a dança, a música e as artes plásticas" (ibid.) ${ }^{5}$. Também certa atitude de contestação poderia indicar uma identificação entre os dois grupos e seus trabalhos, os quais almejam a uma postura combativa para melhor intervir no espaço público. As semelhanças, porém, limitamse à superfície. Pois, se questionamos a possibilidade ou o interesse de uma retomada do caráter vanguardista pretendida por certo teatro contemporâneo, não se tratará aqui de submeter a essa crítica toda e qualquer manifestação cênica que semelhe aspirar a essa impossível passagem para a práxis: pelo contrário, certas obras, como a que aqui se menciona, mostram ter capacidade de justamente incluir em sua forma a reflexão sobre a impossibilidade do rompimento da representação em direção à efetividade, criando interessantes imagens dialéticas, as quais podem ser propulsoras de processos de pensamento inauditos ou pelo menos revigorantes.

Como (ver[ ]ter) faz isso? É preciso se debruçar um pouco sobre algumas das cenas apresentadas. A peça tem início com a entrada dos atores no espaço de intervenção (a partir de 2012, a ação teve lugar sempre no meio da rua, atrapalhando assim o trânsito e gerando bastante incômodo para alguns motoristas); enquanto uma música romântica começa a ser tocada num contrabaixo acústico, eles se juntam em pares e se beijam longamente. A ação seguinte, acompanhada pela ária "Un bel di vedremo" de Puccini cantada por Maria Callas, consiste em um lento movimento de escorregar por um muro até que todos os atores estejam largados no chão, corpos inertes na calçada, interrompendo ritmo e postura corporal habituais, criando obstáculos para transeuntes rápidos e eretos. Em seguida, os Commediens voltam à rua para uma dança improvisada por entre os veículos que circulam habitualmente pela rua; aqui, diferentemente da cena do beijaço, não se interrompe totalmente o tráfego, os performers se inserem nele aproveitando limites entre faixas, semáforos fechados, intervalos entre automóveis como estímulos para composições coreográficas. O que vemos nesse início são interrupções do cotidiano de algum modo semeIhantes às propostas pelo Teatro de Operações, mas com conteúdo bastante diverso: não clichês da intervenção política, mas imagens que assumem seu aspecto primariamente estético, que não pretendem explicitar o próprio engajamento por meio de algum conteúdo explícito.

Em seguida, talvez surpreendentemente para esse teatro de intervenção urbana, os atores saem da rua e adentram um espaço interno. Um ator vendado dança ao som do Requiem de Mozart, atrás dele são projetadas imagens do espancamento de um rapaz pela torcida do time de futebol adversário ao seu ${ }^{6}$ - "uma das cenas de violência que diariamente são captadas por câmeras de segurança e estão presentes em televisores em cada restaurante, cada shopping e cada elevador em São Paulo: daily docu-entertainment de terror", como Röttger (2013, p. 69) descreve a cena7. Os movimentos circulares e repetitivos do ator - imagem da impotência de quem se vê diante desse registro, sequer podendo encarar as imagens - o fazem atingir a tela de projeção, que se deixa levar por seus braços deformando a imagem. No inte-

\footnotetext{
${ }^{4}$ A peça realizou sua temporada de estreia no Centro Cultural São Paulo em maio de 2011, viajando em seguida por diversas cidades, principalmente no interior do estado, retornando à capital para uma segunda temporada na Oficina cultural Oswald de Andrade em agosto de 2012. Apresenta-se até hoje em diversos lugares. ${ }^{5} \mathrm{O}$ Teatro de Operações (2013b) descrevia A cena é pública como constituída de "elementos de circo, teatro, performance, dança, artes marciais e técnicas de rua (como o Le parkour)", em "números independentes e itinerantes".
} 
rior do prédio, um performer brinca com uma navalha e creme de barbear enquanto tranquilamente canta uma canção, passando o instrumento por seus pulsos, mamilos, sua língua; outro ator deita-se em seu colo, e o primeiro passa a navalha lentamente por seu pescoço. A iminência do ato violento, perigo presente desde o início do trabalho (antecipação de possíveis atropelamentos, imagem de corpos jogados no meio-fio, vídeo projetado e tropeções do dançarino vendado), chega aqui a um máximo de tensão, causando aflição e repulsa. Essa violência explode no fundo do prédio, num espaço fechado por tapumes onde são projetadas cenas fortíssimas de filmes pornográficos, imagens contendo não apenas sexo, mas violência (sadomasoquismo, fist-fucking) e humilhação (sobretudo o abuso das atrizes pelos homens), e até um desenho animado japonês ("hentai") com cenas de estupro, com direito a sangue misturado a outros fluidos corporais.

De fato, a Les Commediens Tropicales insiste em imagens insuportáveis, repete incansavelmente certo risco: pôr-se diante de carros e navalhas, se forçar a ver imagens repulsivas. Repetir a cada cena o perigo e as imagens; repetir a peça a cada semana, por um mês ou mais; insistir em novas temporadas ou viagens com a obra: como compreender essa repetição de imagens e gestos autodestrutivos? Há que se distinguir a violência apresentada da suposta radicalidade de uma ruptura com a representação em prol de uma relação crua, não mediada com o real. Ao contrário, a insistência e a repetição podem indicar uma pulsão de morte no sentido freudiano ${ }^{8}$, lógica diferente da (mais habitual) do desejo, não mirando satisfazer uma falta, mas insistir no trauma como falta jamais satisfeita, produzindo gozo justamente em girar em torno de um vazio: no caso, o vazio que constitui o próprio Real (bem diferente, para Lacan, da realidade), que tanto mais se afasta quanto mais os performers o buscam com a intervenção urbana. O Real só é acessado como imagem, ou melhor, pela insistência na imagem, como núcleo ausente em torno do qual as imagens giram.

Aqui, pois, o gesto não é ato que rompe com a representação, mas opera como em Brecht, para quem ele era "exposição da interrupção de todo processo no corpo do homem", correspondendo à "imagem dialética" benjaminiana, "dialética em suspensão, [...] sinalização de um limite não ultrapassável pela exposição artística", limite que mantém o teatro como teatro, sem se fundir com a práxis política (Gatti, 2008 , p.77). A contraposição almejada é produção de novas imagens, contraimagens, que são ainda metaimagens, refletindo sobre imagens dadas para "comungar novos olhares com os espectadores [...] sobre as possibilidades de criar sentidos a partir de velhas histórias e imagens" (Les Commediens Tropicales, op. cit). O risco em cena, como disse em debate sobre a peça o crítico Kil Abreu, não é bem (ou apenas) físico, não trata de saber se o ator será atropelado pelo ônibus que não desacelera, mas risco da ordem do sentido, da lógica implícita de uma sociedade. Se o ritmo habitual dos transeuntes e veículos de São Paulo parece uma imagem petrificada, repetição morta de movimentos reificados, representando um modo de (não- ou mal-) viver na

\footnotetext{
${ }^{6} \mathrm{O}$ cruzeirense Otávio Fernandes, de 19 anos, foi espancado até a morte por torcedores do Atlético-MG com chutes, paus e ferros, dia 27 de novembro de 2010 em Belo Horizonte. As fortes cenas da violência foram captadas por câmeras de segurança de um shopping, e transmitidas nos mais importantes telejornais no país. Diversas prisões foram ordenadas entre 2010 e 2011, e os julgamentos dos acusados se deram em 2012 e 2013. Ver matéria de fevereiro de 2013: http:/l www.gazetadopovo.com.br/esportes/futebol/conteudo.phtml?id=1341292.

${ }^{7}$ Kati Röttger, professora da Universidade de Amsterdã, veio ao Brasil em agosto de 2012 para ministrar uma disciplina na ECA-USP junto com seu colega Alexander Jackob. Na ocasião, pudemos levá-los a assistir a uma apresentação de (ver[ ]ter), o que possibilitou uma riquíssima discussão sobre a obra e a produção do artigo que aqui citamos, publicado pela teórica na Suíça.
} 
metrópole, também a ação do grupo é a imagem de outra forma de pensar e fazer, cuja possibilidade jaz reprimida, invisível no cotidiano.

\section{Do teatro engajado ao teatro do engajamento}

Mencionamos no caso de (ver[ ]ter) como as proposições de cenas intervindo no espaço urbano tinham conteúdo diverso daquele explícita e estereotipicamente político e supostamente radical de A cena é pública, assumindo antes os deslocamentos e as incongruências das relações: beijos trocados e árias cantadas no meio da rua e dos carros, vídeos de violência cotidiana e pornografia pesada combinados aos gestos e danças dos Commediens. Estaremos com isso ambicionando banir os temas explicitamente político de um teatro que evite o espetáculo fetichizado e se pretenda verdadeiramente transgressor? Certamente não será esse o caso, sob o risco de criar com essa proscrição apenas um tabu que necessariamente deveria ser atacado por novas transgressões artísticas. Faz-se imperativo, então, avaliar como certos assuntos e questões, quais sejam, os relativos ao franco engajamento e às tentativas de ações revolucionárias, podem ser tratados sem recair na afetação de uma radicalidade ou efetividade que o fenômeno artístico simplesmente não alcança (pelo menos no atual momento histórico). Para tanto, parece-nos propicio investigar brevemente um trecho da peça Quem não sabe mais quem é, o que é e onde está precisa se mexer, da Cia São Jorge de Variedades, uma das obras mais instigantes do recente teatro paulistano, e uma das primeiras a colocar em cena as formas e os problemas aqui discutidos ${ }^{9}$.

A peça é resultado de um embate da companhia com a obra dramatúrgica de Heiner Müller, visto como mais importante herdeiro e ao mesmo tempo mais agudo crítico de Brecht, permitindo aos artistas um interessante acerto de contas, ao mesmo tempo com a linhagem hegemônica do engajamento cênico (o teatro político teve certa preeminência na São Paulo dos anos 90 e 2000, nele tendo parte a própria São Jorge $\mathrm{e}^{10}$ ) e com os fantasmas da luta política do século XX. É interessante que, para começo dessa obra, a companhia também escolheu a forma da intervenção no espaço urbano: a primeira parte da peça consiste numa volta no quarteirão próximo ao local de apresentação, simulando em quinze minutos a ação revolucionária de um insólito trio. Uma atriz com capa de chuva transparente e peruca loira oxigenada conduz o público, com ordens e recomendações práticas para a subversão (como se esconder da polícia), simulado o risco ou a seriedade do intento político, bradando frases de efeito e colando cartazes com frases de Müller: "A REVOLUÇÃO COMEÇA COM UM PASSEIO", "SOU O MEU PRISIONEIRO" etc. Pelo caminho, surge de bicicle-

\footnotetext{
${ }^{8}$ É notória "uma das funções da repetição, ao menos da forma como foi compreendida por Freud: repetir um evento traumático (nas ações, nos sonhos, nas imagens) de forma a integrá-lo à economia psíquica" (Foster, 2005: p. 166). Lacan explica que Freud, investigando situações em que pacientes repetiam imagens e atitudes traumáticas de modo potencialmente autodestrutivo, fugindo assim à lógica da busca do prazer até então central nas suas pesquisas, descobre no princípio do prazer - ao qual "deu um novo sentido, por instalar no circuito da realidade, como processo primário, a articulação significante da repetição" - uma nova inflexão, a "forçação de sua barreira tradicional pelo lado de um gozo, cujo ser faz-se então revestir pelo masoquismo, e até mesmo se abre para a pulsão de morte" (Lacan, 1998, pp. 71-2).

${ }^{9}$ Pudemos assistir à peça em mais de um local: na Casa de São Jorge (sede da companhia) na temporada de estreia no primeiro semestre 2009, e no semestre seguinte na Casa Livre (situada na mesma vizinhança da Barra Funda); no Galpão do Folias (Santa Cecilia) em setembro de 2011, na mostra "O Mundo É o Que se Vê de Onde Está"; novamente no Teatro Adamastor, em Guarulhos, em novembro de 2014, quando a peça foi retomada em projeto de circulação pelo estado de São Paulo. Finalmente, a gravação de uma apresentação realizada na Caixa Cultural do Rio de Janeiro em abril de 2011 está disponivel integralmente na internet, no endereço http://vimeo.com/29083491.
} 
ta outra histérica figura com um capacete espacial, um colete vermelho coberto de adesivos com o título da peça, gritos agudos e panfletos. No percurso o terceiro ator se transforma de executivo engravatado a índio sem camisa, de cocar e short azul, e murmura um trecho de A missão, de Müller, do qual ouvimos frases soltas. Contrarregras erguem sobre as ruas, atrapalhando o trânsito, faixas dizendo "AQUELE QUE NÃO SE MEXE NÃO SENTE AS GRADES QUE O APRISIONAM" e "A CONTINUIDADE ROTINEIRA GERA A DESTRUIÇÃO".

Ora, não vemos também aqui imagens que almejam certa radicalidade política explícita? Mas, ao contrário de um pretenso teatro performativo ou de uma duvidosa passagem para o campo da práxis, são escancarados aqui o caráter representado de cada ação, a teatralidade dos gestos, a farsa que está sendo encenada. É bem verdade que, diante do portão fechado do Teatro São Pedro, a primeira das atrizes declara por meio de um célebre discurso de Hamlet Máquina ter desistido da representação teatral: "Eu não sou mais Hamlet. Não represento mais nenhum papel. Minhas palavras já não me dizem mais nada. Meus pensamentos sugam o sangue das imagens. Meu drama não se realiza mais. Diante de mim monta-se a cena, por pessoas às quais o meu drama não interessa, para pessoas às quais ele nada importa. A mim ele também não interessa mais. Eu não entro mais." E no entanto, como nota o crítico Luiz Fernando Ramos (2009), permanece uma ambiguidade nesse abandono da representação, "pois eles [atrizes e ator] vestem figurinos e jogam com os espectadores um faz de conta de que se vive uma ação revolucionária"; do que resulta que, "quando se retorna ao espaço da companhia, qualquer encanto que aquelas ações pudessem ter sugerido já se tornou contrafação". Os atos revolucionários são representados demais, sempre algo de ridículo, de tosco; a falsidade da cena teatral é sempre assumida, a ingenuidade da ação e do discurso revolucionários é óbvia e merece a irrisão a todo momento; o próprio espaço da rua como palco de uma intervenção radical e inesperada parece já estar institucionalizado, normalizado. Assim, se de fato a São Jorge encena gestos de algum modo comparáveis ao do Teatro de Operações, a peça foge à sedução ilusória do espetáculo ao colocar radicalmente em questão os próprios gestos e as próprias cenas, ao se expor a uma profunda e corajosa autocrítica.

Não trataremos, aqui, da continuação da peça, em que os atores voltam para a sede da companhia, transformada em QG revolucionário (ou apartamento de classe média); vale dizer que essa sequência "não é um drama, ou uma história que se queira narrar", mas "espécie de faxina geral [...] nos procedimentos supostamente engajados e nas aspirações pretensamente elevadas que ainda se possam cultuar" (ibid.). Segundo Kil Abreu (2012: p. 231) a peça acerta ao "assumir, parcial ou totalmente, o aspecto de dificuldade no tratamento dos materiais disponíveis, de maneira que a própria forma denuncie uma crise que vai se instalar com maior ou menor espaço no centro do representado". Mas não se trata também de pura destruição pessimista das cren-

\footnotetext{
${ }^{10}$ Trata-se do que Sérgio de Carvalho chamou de terceiro ciclo de politização do teatro brasileiro: "São momentos em que a produção artística mais experimental assume uma orientação crítica de sentido extra-estético, em que predomina o interesse na participação em debates públicos, em que várias experiências isoladas passam a se conjugar em torno da tomada de posições coletivas diante de processos históricos" (Carvalho, 2011). Depois do ciclo "virtual" dos anos 20 e 30 mais literário que cênico, com os textos antiburgueses de Oswald de Andrade - e de um segundo nacional-popular (e já de certo modo brechtiano), com o Teatro de Arena à frente, esse terceiro ciclo surge por "uma série de razões ligadas a ausência de condições produtivas estáveis" (ibid.) e início com o movimento "Arte contra a barbárie" (1998-2005), alcançando a organização de diversos grupos em um debate uno e a Lei de Fomento ao Teatro para a Cidade de São Paulo (até hoje modelo de política pública para as artes no Brasil).
} 
ças de outrora; pelo contrário, a comédia da Cia São Jorge não significa apenas rir das aspirações elevadas, mas também elevar o riso a aspiração política. Não é apenas derrisão a acusar o discurso revolucionário, mas também riso provocando uma suspensão dialética, elevação a um novo patamar, nova possibilidade de fazer sentido.

Quem não sabe mais... mostra como apenas personagens de comédia, armados da consciência do próprio ridículo, ainda podem ter a ousadia de manter uma posição política radical. As duas visões contrárias, o ridículo de ter algo a dizer e a relevância insistente do que o próprio ridículo diz, são afinal dialeticamente idênticas; as duas solapam a velha oposição entre sentido superior e derrisão cética/cínica, racional e irracional, engajamento e alienação; simplificações que frequentemente serviram no teatro brasileiro para classificar grupos e obras, e que muitos querem ressuscitar de modo abusivamente direto. Ou ainda, poderíamos dizer: a peça da São Jorge transgride os limites entre esses extremos vistos como opostos excludentes, recoloca a questão, redistribui as posições em jogo, possibilitando um novo olhar sobre o que são os gestos verdadeiramente revolucionários. Justamente aqueles que se confundem e misturam com a imagem, que afirmam o estético, não temendo serem taxados de esteticismo ou subjetivismo alienado.

\section{Uma transgressão do olhar}

Poderíamos dizer que (ver[ ]ter) e Quem não sabe mais quem é, o que é e onde está precisa se mexer ainda possuem uma característica em comum com A cena é pública, no que diz respeito ao potencial de transgressão que cada uma dessas obras poderia trazer em si: nas três, certa radicalidade dissensual (em relação aos modos dados de percepção e comportamento no cotidiano) se manifesta pela presença ativa dos corpos dos atores ou performers no espaço público, pelo seu empenho e desempenho em produzir ações, gestos e cenas, em desenhar imagens efêmeras mas de profunda pregnância sobre a superfície urbana. O que não significa afirmar que as três peças já citadas o façam exatamente da mesma maneira. Se o grupo carioca parecia contar com a energia positiva dos sujeitos que realizavam as "Operações" propostas, isso é, com sua capacidade de fazer intervir certa ideia de transgressão traduzida em cena teatral (a de uma força purificadora na lavagem das bandeiras, a de um bizarro circo da política na luta dos candidatos, a da necessidade e potência de se contrapor à sociedade do espetáculo na destruição dos televisores), os Commediens paulistanos pareciam proceder de modo quase oposto: deixando-se cair por muros e calçadas, arriscando serem atropelados ou agredidos, submetendo-se a diversas violências (das imagens filmadas e projetadas, mas também do cotidiano urbano), os artistas parecem afirmar mais sua passividade, que poderia ser também vista como uma profunda permeabilidade para os fluxos de movimentos e conjuntos de forças e tensões presentes e atuantes no espaço urbano, uma paradoxal potência da impotência, atividade de se deixar afetar que transgride os usos habituais da rua quanto mais frágil e mesmo fraca parece ser, e que poderia nos remeter mais à mimeses adorniana que às teorias do performativo11. Já a São Jorge parece propor uma terceira forma de intervenção dos corpos no espaço, que combina elementos das duas formas anteriores: se por um lado os atores propõem cenas que intervêm no 
espaço energicamente, por outro eles mesmos duplicam-se para revelar o caráter de simulação e dissimulação dessas pretensas ações revolucionárias, criando imagens dialéticas e propondo um corpo que reflete crítica e derrisoriamente sobre a própria atividade ao mesmo tempo que a realiza alegre e carismaticamente.

No entanto, antes de concluirmos algo sobre as possibilidades de se falar em alguma transgressão na cena paulistana contemporânea, devemos nos debruçar sobre mais uma de suas obras recentes, que de algum modo escapa justamente ao que dissemos ser comum às outras peças estudadas: em $O$ farol, do Coletivo OPOVOEMPÉ ${ }^{12}$, não haverá justamente o elemento considerado frequentemente o mais fundamental para o teatro de intervenção urbana, isso é, a interrupção do fluxo cotidiano pela interferência dos corpos no espaço urbano. O que se propunha, pelo contrário, era um percurso do próprio espectador - tornado centro da ação cênica - por diversos espaços da cidade de São Paulo, retirando-se os atores para a posição de meros guias ou, pontual e sutilmente, provocadores da experiência estética calma e silenciosa. Os artistas sequer falam muito com os viajantes: a maior parte da mediação é realizada por um aparelho de MP3 recebido no início do trabalho, e que soma à profusão de estímulos visuais uma série de sons, músicas, textos reflexivos e perguntas, cuidadosamente compostos em relação a cada espaço visitado. É como se a mimeses adorniana encontrada em (ver[ Jter) fosse levada às últimas consequências, de modo que o sujeito da obra (tanto o artista quanto o espectador) se tornou pura capacidade de afecção, ou como a câmera de um filme documentário puro olhar, órgão sem corpo.

Assim, desde o ponto de encontro no Hotel Sheraton da Berrini (região que representa o ápice do capital financeiro na pretensa cidade-global, e que por si só dista bastante dos lugares que um espectador de teatro costuma frequentar), passando por todo o complexo do World Trade Center, pela estação e pelo trem da CPTM, até chegar ao bairro de Presidente Altino, já em Osasco, a obra do OPOVOEMPÉ se desenvolve pelo caminho oposto ao acontecimento imperativo e ao alarde festivo normalmente associados à ideia de transgressão, pelo menos no teatro. Aqui, tratase muito mais de navegar pelos fluxos de movimentos já existentes no espaço, criando caminhos insólitos e possibilidades reflexivas, surpreendendo o espectador (e a si mesmo) com imagens ao mesmo tempo cotidianas e inesperadas, absolutamente banais e estranhamente enigmáticas; é o caso da visita a um andar vazio do prédio de escritórios do WTC, onde encontramos apenas um faxineiro solitário e uma enorme janela para a cidade, a qual nos darão (e nos daremos) o direito de contemplar longamente. Lá embaixo o ritmo pulsante da metrópole, os carros tornados minúsculos, os pedestres mal perceptíveis. Mas também as cicatrizes de batalhas silenciosas: 0 shopping Cidade Jardim com sua arquitetura de fortaleza de luxo, o conjunto habitacional Cingapura (pequena lembrança das favelas expulsas daqui para permitir a criação desse novo pólo econômico), a enorme e desnecessária Ponte Estaiada que

\footnotetext{
${ }^{11}$ Apesar da posição do próprio grupo, que fez acompanhar a temporada de (ver[ ]ter) na Oficina Cultural Oswald de Andrade por um "Colóquio sobre teatro performativo", lembremos que Adorno propunha por meio de sua formulação original do conceito de mimese uma relação complexa - sem possibilidade de passagem imediata - entre o território autônomo da arte e o mundo da práxis. Na mimeses, "o sujeito se deixa atingir, afetar pelo objeto, mas esse toque recíproco não produz feridas; o sujeito não apaga nem submete o outro a si mesmo num gesto prepotente" (Gagnebin, 1993, p. 85).

${ }^{12} \mathrm{O}$ farol era parte da trilogia A Máquina do Tempo (ou Longo Agora), criada em 2012 pelo grupo em torno de uma reflexão sobre a experiência do tempo na contemporaneidade (o subtítulo dessa primeira parte da trilogia é "Uma contemplação da velocidade"). A peça só teve uma temporada, entre junho e julho de 2012, devido às dificuldades da produção. Foram doze dias, com treze sessões cada - como eram individuais ou em dupla, a peça pôde ter no máximo 312 espectadores no total. Para nossa análise seguimos, por isso, anotações feitas após vê-la uma única vez. As outras duas partes da trilogia se chamavam 0 espelho - uma contemplação da vida e da finitude e A festa - compartilhar o agora.
} 
leva o nome de um magnata da imprensa brasileira.

Depois de nos colocar diante de tanta realidade, OPOVOEMPÉ nos levará ao gigantesco e vazio "Centro de Convenções Golden Hall". No centro do imenso salão oval sem janelas, nosso guia nos abandona temporariamente enquanto lentamente dá uma volta completa em seu perímetro; a tremenda impressão sensível é sublinhada pela trilha sonora que adquire um tom quase sagrado. Um dos maiores méritos de O farol é criar para o espectador uma sensação concreta do que Rem Koolhaas, arquiteto e teórico da cidade pós-moderna, nomeou "Grandeza" (Bigness): "a distância entre o centro e o invólucro aumenta até ao ponto em que a fachada já não revela o que acontece no interior. A exigência humanista de 'honestidade' está condenada: as arquiteturas do interior e do exterior tornam-se projetos separados, uma confrontando-se com a instabilidade das necessidades programáticas e iconográficas, a outra - agente de desinformação - oferecendo à cidade a aparente estabilidade de um objeto. Onde a arquitetura revela, a grandeza assombra; a Grandeza transforma a cidade, que era uma soma de certezas e passa a ser uma acumulação de mistérios. $O$ que vemos já não é o que nos mostraram" (2010, p. 17).

O farol tem caráter transgressor justamente em sua calma, sua confiança na capacidade estética de criação e contemplação de imagens, por apostar na silenciosa potência do olhar. Instaurando uma poética da ausência, na retirada de cena dos atores, transgride a divisão habitual ao fenômeno cênico entre atividade e passividade, ator e espectador (sem forçar o segundo à condição supostamente mais potente e "emancipada" do primeiro). Não se impõe sobre a cidade para orgulhosamente destruí-la, impõe-na sobre si, mesmo em seus aspectos mais reificados e perversos, para destruir o próprio olhar viciado, petrificado. A maior transgressão dos atores e espectadores da peça é a de si.

\section{O teatro apesar de tudo: partilhas e fracassos}

Como vimos, boa parte das obras e teorias que almejam encontrar um lugar possível de transgressão para a atividade teatral e artística em geral toma como ponto de partida a recusa de categorias tradicionais do fenômeno estético, como a representação ou a imagem, vistas como cúmplices de uma sociedade do espetáculo. Afinal, como diz o teórico e curador Nicolas Bourriaud (um dos mais conhecidos nomes dessa corrente antirrepresentacional) "em uma época em que as representações se interpõem entre as pessoas e sua vida cotidiana, ou entre os próprios seres humanos, é absolutamente normal que a arte por vezes se afaste da representação e se torne parte da realidade em si" (2009: p. 196). Para os adeptos dessa linha, a estetização e espetacularização da política seriam "coisas ruins porque divergem a atenção dos objetivos práticos do protesto político e para sua forma estética", de modo a "neutralizar o efeito prático" da ação (Groys, 2014, p. 1-3).

E no entanto, o que vimos nas peças paulistanas escolhidas para nossa investigação foi justamente o inverso: a aposta no potencial político do próprio estético, e particularmente naquilo que muitas vezes é o mais criticado nele: a predominância 
da dúvida sobre a certeza, da simulação sobre a autenticidade, da duplicação sobre a unidade inequívoca. Contra o "artivismo" o mais das vezes muito seguro de si e da própria capacidade de intervir no mundo da práxis, os mais interessantes trabalhos do recente teatro paulistano reafirmam a distância reflexiva da experiência estética, distância que instaura a dúvida no cerne de toda experiência cotidiana do mundo, desrealizando experiência e mundo, abrindo ambos ao olhar estetizante. Porque estetizar não significa um mero e pernicioso enfeitar; pelo contrário, "em um contexto artístico, estetizar as coisas do presente significa descobrir seu caráter disfuncional, absurdo, inoperável - tudo que as faz não-utilizáveis, ineficientes, obsoletas" (Groys, op. cit., p. 6). Isso é, ao estetizar o presente as peças aqui analisadas buscam "transformá-lo no passado morto"; mesmo quando os artistas parecem aceitar o status quo (como poderia parecer na passividade dos performers de (ver[ ]ter), na derrisão do intuito revolucionário em Quem não sabe mais... e também na retirada de cena dos atores em $O$ farol), essa produção "aceita-o como um cadáver, depois de sua transformação em mera representação" (ibid.).

Ou seja, é justamente o caráter não-vivo da representação, vilipendiado pelos defensores de um teatro "do real", que garante sua potência estética e política. Em oposição "ao ato de palavra 'vivo', conduzido pelo locutor ao seu destinatário adequado", o fenômeno estético se afirma como "superfície muda dos signos pintados" (Rancière, 2005, p. 21), disponíveis para o olhar de um espectador qualquer que os leia por conta própria, sem a imposição de um sentido pelo artista, como de fato parece ser o caso do artivismo e dos teatros performativos ou do real. Com sua certeza do próprio sentido, as cenas desse teatro antirrepresentativo tornam-se mercadorias vendáveis, a transgressão pretendida se inverte no espetáculo que queria destruir. São as imagens que se assumem enquanto tal, que se sabem diferentes e distanciadas do "real", que podem transformar o real em enigma, dialetizá-lo, fazê-lo tropeçar. Com isso queremos dizer: transgredi-lo realmente, transgredir as separações estanques entre visível e invisível, dizível e indizível, entre aqueles que podem e aqueles que não podem falar; transgredir a separação entre o possível e o impossível, entre o mundo tal qual ele é e o mundo tal qual ele poderia ser: ao "arrancar algumas imagens" ao real, os artistas arrancam "ao pensamento humano em geral o pensamento do 'fora', um imaginável para aquilo de que ninguém [...] entrevia a possibilidade" (Didi-Huberman, 2012: p. 19). Assim como toda arte, "o ativismo artístico não pode escapar de uma tradição muito mais radical e revolucionária da estetização da política - a aceitação do próprio fracasso, entendido como premonição e prefiguração do fracasso por vir do status quo em sua totalidade, não deixando espaço algum para sua melhora ou correção possíveis" (Groys, p. 10). 


\section{Referências}

ABREU, K. "A cultura do fomento: grupos, fatura estética e relações criativas". In: Desgranges, Flávio e Lepique, Maysa (orgs.). Teatro e vida pública: o Fomento e os coletivos teatrais de São Paulo. São Paulo: Hucitec/Cooperativa Paulista de Teatro, 2012, pp. 224-37.

BOURRIAUD, N. Estética relacional. São Paulo: Martins Fontes, 2009.

DIDI-HUBERMAN, G. Imagens apesar de tudo. Lisboa: KKYM, 2012.

FÉRAL, J. "Por uma poética da performatividade: o teatro performativo". In: Re vista Sala Preta, vol. 8, no 1, 2008, pp. 197-210.

FERNANDES, S. "Experiências do real no teatro". In: Revista Sala Preta, vol. 13, no 2, 2013. Disponível em: http://www.revistas.usp.br/salapreta/article/view/ 69072. Acesso em: 30 de janeiro de 2014.

FISCHER-LICHTE, E. The transformative power of performance: a new aestheti cS. Abingdon: Routledge, 2008.

FOSTER, H. "O retorno do real". Revista Concinnitas, ano 6, volume 1, número 8, julho de 2005, pp. 163-186.

GAGNEBIN, J.-M. “Do conceito de mímesis no pensamento de Adorno e Benja min". In: Perspectivas, São Paulo, v. 16, 1993, pp. 67-86.

GALARD, J. A beleza do gesto. São Paulo: Edusp, 2008.

GATTI, L. "Benjamin e Brecht: a pedagogia do gesto". In: Cadernos de filosofia alemã, no 12, julho-dezembro de 2008, pp. 51-78.

GROYS, B. "On art activism". In: e-flux journal, no 56, junho de 2014. Disponível em: http://www.e-flux.com/journal/on-art-activism/. Acesso 05 de julho de 2014.

KOOLHAAS, R. Três textos sobre a cidade. Barcelona: Gustavo Gili, 2010.

LACAN, J. Escritos. Rio de Janeiro: Jorge Zahar, 1998.

LAVANDER, A. Theatres of engagement. Londres: Routledge, 2015.

LES COMMEDIENS TROPICALES. "(ver [ ] ter)" (release). Disponível em: http://festival 
riopreto.com.br/2012/programacao/ver.php?espid=57. Acesso em 30 de agosto de 2012 .

MARCUSE, H. One-Dimensional Man: Studies in the ideology of advanced in dustrial society. Abingdon: Routledge: 2002.

RAMOS, L. F. "Grupo usa poesia como base para peça política corrosiva”. Folha de São Paulo, 25 de junho de 2009. Disponível em: http://www1.folha. uol.com.br/fsp/ ilustrad/fq2506200909.htm. Acesso em 27 de julho de 2013.

"Hierarquias do Real na Mímesis Espetacular Contemporânea". In: Revista brasileira de estudos da presença, Porto Alegre, v. 1, n. 1, p. 61-76, janeiro-junho de 2011. Disponível em http://seer.ufrgs.br/index.php/presenca/ article/view/22044/13693. Acesso: 5 de janeiro de 2014.

Mimesis performativa: a margem de invenção possível. São Paulo: Annablume, 2015.

RANCIÈRE, J. A partilha do sensível: estética e política. São Paulo: EXO Experi mental/Editora 34, 2005.

RÖTTGER, K. "Die Frage nach dem Medium der Choreographie". In: Angerer, Marie-Luise et al. (org.). Choreographie - Medien - Gender. Zurique: Diaphanes, 2013, pp. 57-77.

SAISON, M. Les théâtres du réel: pratiques de la représentation dans le théâtre contemporain. Paris-Montreal: L'Harmattan, 1998

SÁNCHEZ, J. Prácticas de lo real en la escena contemporánea. Madrid: Visor, 2007.

TEATRO DE OPERAÇÕES. "O teatro como um pequeno mundo, o mundo como um grande teatro". 2013 (a). Disponível em: http://www.teatrodeoperacoes. com/pt/?/grupo/sobre/. Acesso em 25 de agosto de 2015.

"A cena é pública". 2013 (b). Disponível em: http://www. teatrodeoperacoes.com/pt/?/operacoes/a-cena-e-publica/. Acesso em 25 de agosto de 2015 .

Recebido em: 29/04/2016 Aprovado em: 01/07/2016 